Ritrýnd grein birt 15. desember 2019

\title{
Mat á stöðu faglegs lærdómssamfélags í grunnskóla: próun mælitækis
}

\author{
Berglind Gísladóttir, Auður Pálsdóttir, \\ Anna Kristín Sigurðardóttir og Birna Svanbjörnsdóttir \\ Abstract \\ Um höfundana \\ About the authors \\ Heimildir
}

Markmið pessarar rannsóknar er tvípætt. Annars vegar að draga fram pá pætti sem einkenna lærdómssamfélag í íslenskum grunnskólum og hins vegar að próa mælitæki sem gefur upplýsingar um stöðu lærdómssamfélags innan hvers skóla. Tilgangur slíks mælitækis er að fá yfirlit um stöðuna í hverjum skóla og gögn um helstu styrkleika og áskoranir sem próun lærdómssamfélags innan skólans stendur frammi fyrir. Slíkar niðurstöður má nota af starfsfólki skólans til að rýna í eigið starf en einnig til að sníða ráðgjöf og leiðsögn að pörfum á hverjum stað eða ákveða hvert megi beina starfspróun starfsfólks skólans. Mælitækið er spurningalisti með staðhæfingum sem mótaður var á grunni annarra spurningalista sem höfðu verið notaðir hér á landi og hann próaður áfram. Forprófun fór fram meðal kennara og stjórnenda í 13 skólum og eftir gagngera endurskoðun var listinn lagður fyrir í 14 skólum til viðbótar.

Niðurstöður leiddu í ljós sex vel afmarkaða pætti sem eru að mestu leyti í samræmi við fyrri rannsóknir á einkennum lærdómssamfélags í skólum. Dættirnir eru (I) sameiginleg sýn og gildi, (II) gagnrýnin ígrundun eigin kennslu, (III) faglegur stuðningur við próun kennsluhátta, (IV) dreifð og styðjandi forysta, (V) félagslegt andrúmsloft styður samstarf og (VI) starfsánægja. Næstu skref eru að staðfesta (e. validate) listann með hliðsjón af pátttöku fleiri skóla og eigindlegum viðtölum um sýn pátttakenda á hvort niðurstöður peirra skóla rími við upplifun peirra og reynslu af starfinu í skólanum.

Efnisorð: Faglegt lærdómssamfélag, mælitæki, grunnskóli

\section{Inngangur}

Rannsóknir á skólastarfi hafa sýnt að einn pýðingarmesti pátturinn í umbótum í skólastarfi er samstarf fagfólks innan hvers skóla (Darling-Hammond, 2017; Kools og Stoll, 2016; Vieluf, Kaplan, Klieme og Bayer, 2012). Slíkt samstarf snýst um að próa ákveðna starfspróunarmenningu sem felst 1 a đ kennarar og skólastjórnendur eru stöðugt að læra í starfi, endurskoða og bæta skólastarfið, námi nemenda til heilla (Jensen, Sonnemann, Roberts-Hull og Hunter, 2016; OECD, 2019).

Hugtakið lærdómssamfélag er víða notað. Skilgreining pess hefur byggst á niðurstöðum rannsókna á skólastarfi par sem sjónum er beint að pví hvers konar skólamenning og aðstæður virðast ríkja í skólum par sem samstarfshópurinn axlar sameiginlega ábyrgð á námi og árangri nemenda (Vesco, Ross og Adams, 2008). Detta kemur einnig fram í skilgreiningu Samstarfsráđs um starfspróun kennara og skólastjórnenda en par er bent á að einkenni lærdómssamfélags í skólum byggist 
á fagmennsku, teymisvinnu, ígrundun í námi og starfi og árangursríkri starfspróun (Mennta- og menningarmálaráđuneytið, 2019). Tilgangurinn með próun slíks lærdómssamfélags er að greina með skipulegum hætti hvernig best megi búa svo um hnútana að starfsmenn skóla læri hver af öðrum og hver með öðrum til að bæta nám allra nemenda skólans.

Í lögum um grunnskóla nr. 91/2008 segir að markmið mats á skólastarfi sé m.a. að auka gæði náms og skólastarfs og stuðla að umbótum, en einnig að petta mat purfi að fara fram með kerfisbundnum hætti. Staða skóla sem lærdómssamfélags hefur í íslenskum og erlendum rannsóknum verið tengt við árangur skóla (Anna Kristín Sigurðardóttir, 2010; Dogan og Adams, 2018). Íslenskir skólar virðast standa frammi fyrir áskorunum og hallar á íslenska nemendur pegar árangur peirra er skoðaður í alpjóðlegum samanburði (Menntamálastofnun, 2017). Dví er áríðandi að efla möguleika kennara til að rýna saman í starf sitt með kerfisbundnum hætti og gera peim kleift að nýta gögn og upplýsingar á skipulagðan hátt.

Rannsóknir benda til að meta megi stöđu lærdómssamfélags í hverjum skóla fyrir sig. Í pví samhengi virðist mikilvægt að taka tillit til bæði innri og ytri pátta, p.e. pess sem snýr að kennurunum sjálfum og pess sem snýr að starfsumhverfi peirra og stofnanamenningu. Hins vegar benda rannsóknir einnig til pess að taka verði mið af menningu og aðstæðum á hverjum stað pví bæði lagarammi og hefðir eru um margt ólíkar eftir ríkjum heims. Dví sé ekki hægt að yfirfæra mælingar á teiknum um lærdómssamfélag frá öđrum pjóðum beint yfir á íslenskar aðstæður. Pá bendir samanburður erlendra rannsókna og vísbendingar úr innlendum rannsóknum til pess að fjöldi pátta sem mæla stöðu lærdómssamfélags í skólum sé ekki klipptur og skorinn. Markmið pessarar rannsóknar er pví tvípæett. Annars vegar að draga fram pá pætti sem einkenna lærdómssamfélag í íslenskum skólum og hins vegar að próa mælitæki sem gefur upplýsingar um stöđu lærdómssamfélags innan hvers skóla. Slíkar niðurstöður má nota innan skólans af starfsfólki hans til að rýna í eigið starf, greina áskoranir og styrkleika pess svo hægt sé með markvissari hætti að slípa starfshættina í anda lærdómssamfélags. Einnig má nota niðurstöðurnar til að sníða ráðgjöf og leiðsögn að pörfum á hverjum stað eða ákveða hvernig skuli standa að starfspróun starfsfólks skólans.

\section{Starfspróun kennara á Íslandi}

Kröfur um dýpra og flóknara nám nemenda hafa aukist mikið undanfarna áratugi. Aukin áhersla er á hæfni nemenda sem purfa að fóta sig í hratt vaxandi heimi fagpekkingar, að peir geti beitt gagnrýninni hugsun, leyst flókin viðfangsefni, átt í skilvirkum samskiptum og samstarfi og unnið sjálfstætt. Í pessu felast breyttar kröfur til kennara og pess starfs sem unnið er í skólum. Til pess að mæta peim parf skipulegan stuðning við kennara sem purfa bæði tíma og svigrúm til að rýna markvisst í og endurskoða eigið starf (Darling-Hammond, Hyler og Gardner, 2017; OECD, 2019).

Starfspróun kennara á Íslandi virðist vera með nokkuð öðrum hætti en víða erlendis. Í TALIS-rannsókninni sem Ísland hefur tekið pátt í árin 2008, 2013 og 2018 eru kennarar og skólastjórnendur á unglingastigi grunnskóla meðal annars spurðir um aðgengi peirra að og reynslu af starfspróun og samstarfsmenningu kennara (OECD, 2019). Fram kemur að skólar sem ná mestum árangri grundvalla starf sitt á formgerðu lærdómssamfélagi sem felur í sér skipulagt samstarf kennara og stjórnenda sem fá reglulega endurgjöf um störf sín og hugmyndir frá samstarfsfólki. Dessi endurgjöf grundvallast á jafningjarýni og notkun upplýsinga um skólastarfið og úr pví (OECD, 2019). Niðurstöður TALIS-rannsóknanna benda til að skipulegri starfspróun á Íslandi í grunnskólum á unglingastigi sé um margt ábótavant. Til að mynda fá kennarar í mun minna mæli endurgjöf varðandi starf sitt en tíðkast að meðaltali í TALIS-löndunum (Ragnar F. Ólafsson, 2014). I niðurstöðum TALIS 2018 kemur fram að hlutfall peirra kennara, sem pjálfuðu eða fylgdust með kennslu samkennara og/eða greindu eigin kennslu í formlega skipulögðu samstarfi í skólanum, er nærri helmingi lægra á Íslandi $(23,4 \%)$ hvort sem litið er til pátttökuríkja OECD (43,9\%) eða meðaltals TALIS 2018 (49,3\%). Einnig kemur fram að talsvert hærra hlutfall kennara á Íslandi $(61,2 \%)$ segist taka pátt í starfspróun sem felst í vettvangsferðum í aðra skóla, hvort heldur 
sem miðað er við hlutfallið á Norðurlöndum (25,3\%), meðaltal pátttökuríkja OECD (25,9\%) eða meðaltal TALIS 2018 (29,5\%). Virðist petta hafa aukist nokkuð frá 2013 (Ragnar F. Ólafsson, 2019). Dess háttar starfspróun, sem hvílir að mestu á heimsóknum í aðra skóla, mætir ekki ein og sér kröfunni um eða byggir brú yfir í breytta starfshætti. Meira virðist purfa að koma til.

Í umfangsmikilli rannsókn á starfsháttum í grunnskólum á Íslandi (Gerður G. Óskarsdóttir o.fl., 2014) kom fram að kennarar væru ekki alls kostar ánægðir með eigin kennslu. Með starfsháttum er átt við skipulag og nýtingu námsumhverfis, stjórnun og skipulag skólanna, kennsluhætti, nám nemenda, tengsl skóla við foreldra og grenndarsamfélag ásamt viðhorfi til skólastarfsins. Gögnum var safnað í 20 grunnskólum í fjórum sveitarfélögum á landinu. Niðurstöður sýndu að bein kennsla væri ráðandi og nemendur væru piggjendur með takmörkuð áhrif á skipulag og framvindu námsins. Í spurningakönnun og viðtölum kom hins vegar fram að kennarar væru áhugasamir um að beita fjölbreyttari aðferðum í auknum mæli. Sömu vísbendingar hafa komið fram í samhengi við innleiðingu nýrra námssviða og náttúrufræðimenntun (Auður Pálsdóttir, 2014, 2017). Dessar vísbendingar um að vilji kennara til breytinga sé fyrir hendi eru mikilvægar. Af einhverjum ástæðum virðist umgjörðina fyrir breytingar pó skorta og pá helst í hvað kennarar eigi að rýna og með hvaða hætti.

Í rannsóknum á áhrifaríkri starfspróun og alpjóðlegum samantektum fyrir stefnumörkun um starfspróun kennara er lögð áhersla á að móta og próa menningu og skipulag skóla sem hvetur til pess að starfsmenn læri hver af öðrum og hver með öðrum í peim einlæga ásetningi að bæta nám allra nemenda skólans. Slíkt samfélag fagfólks einkennist af samvinnu, fagmennsku, teymisvinnu, sameiginlegri ábyrgð á námi nemenda, ígrundun náms og starfs og árangursríkri starfspróun (Anna Kristín Sigurðardóttir, 2013; Bredeson, 2003; Senge o.fl., 2000; OECD, 2019). Í umræðu um niðurstöður og hvaða leiðir virðast færar til að styrkja skólastarf og auka árangur nemenda er bent á mikilvægi og gildi próunar lærdómssamfélags í skólum (OECD, 2019, bls. 31, 63). Darling-Hammond o.fl. (2017) benda á, í albjóðlegri samantekt, að stjórnvöld og skólastjórar purfi að auka tækifæri kennara til pátttöku í lærdómssamfélagi innan skóla, ráđgjöf um og rýni í kennslu jafningja og samstarf við undirbúning kennslu. Dessi áhersla á aukið samstarf kennara birtist nýverið í íslenskum stefnuskjölum og tillögum. Í stöðuskýrslu íslenskra stjórnvalda um framgang heimsmarkmiða Sameinuðu pjóðanna (markmið fjögur um menntun) segir að eitt af fimm meginpemum heimsmarkmiðanna sé samstarf, að efla verði faglegt sjálfstæði kennara og leggja áherslu á skólapróun á öllum skólastigum (Stjórnarrád Íslands, 2018, bls. 21). Í tillögum Samstarfsráðs um starfspróun kennara og skólastjórnenda til menntamálaráðherra er petta áréttað og lögð áhersla á að tryggja purfi öllum kennurum og skólastjórnendum nægilegt svigrúm innan árlegs vinnutíma til starfspróunar og virkrar pátttöku í lærdómssamfélagi (Mennta- og menningarmálaráđuneytið, 2019). Rannsóknir á próun skólastarfs undanfarna áratugi benda einnig til að starfspróun kennara eigi að fléttast inn í almenn störf kennara og vera hluti af daglegum störfum peirra (Bredeson, 2003; Fullan, 2016; Joyce og Showers, 2002). Dá benda rannsóknir á megineinkennum árangursríkrar starfspróunar á að hún felist í (1) skýrri áherslu á inntak náms, (2) virkri pátttöku par sem tekið er mið af kenningum um nám fullorðinna í starfi, (3) stuðningi við samstarf og ramma utan um pað, (4) notkun fyrirmynda/líkana um góða starfshætti, (5) pjálfun og stuðningi sérfræðinga, (6) tækifærum til að fá og veita endurgjöf og (7) að breytingar festist í sessi (Darling-Hammond o.fl., 2017). Dessi einkenni árangursríkrar starfspróunar ríma vel við niðurstöður rannsókna á einkennum og árangri lærdómssamfélags innan skóla.

\section{Lærdómssamfélag í skólum, einkenni og árangur}

Til eru margar leiðir við að lýsa einkennum lærdómssamfélags í skólum. Allar skilgreiningar snúast um að geta skipulega greint bæði innri og ytri pætti sem móta og viðhalda lærdómssamfélagi í skólum. Hord (1997) sem var einna fyrst til að lýsa einkennum lærdómssamfélags í skólum kynnti fimm meginpætti sem eru (1) sameiginleg sýn og gildi, (2) dreifð og styðjandi forysta, (3) gagnvirkt nám, (4) gagnrýnin ígrundun (e. reflective dialogue) og (5) gagnkvæmur stuðningur. Niðurstöður rannsókna Stoll, Bolam, McMahon, Wallace og Thomas (2006) bentu til svipaðra 
einkenna og Hord en greindu að auki sameiginlega ábyrgð og gagnkvæmt traust og virðingu sem sérstök einkenni. Anna Kristín Sigurðardóttir (2013) tengir skilgreiningar á lærdómssamfélagi saman í hringferli stöðugrar pekkingarsköpunar sem verður til við gagnrýna ígrundun í árangur daglegs starfs. Detta hringferli er stutt af ýmsum menningarbundnum páttum og skipulagi innan skólans. Vaxandi hluti af pessu ferli hefur í seinni tíð beinst að nýtingu hlutlægra gagna í faglegu námi og við töku ákvarðana um skólastarfið (Brown og Zhang, 2017; Burns o.fl., 2017; Huffman o.fl., 2016). Í öllum skilgreiningum á faglegu lærdómssamfélagi er forysta undirliggjandi práður (Birna Svanbjörnsdóttir, 2015). Er henni gjarnan líkt við sérstakt afl í skólasamfélaginu og forsendu pess að skólastarfið nái að próast og eflast. Hér er ekki vísað til pess að skólastjórnendur einir sinni forystu heldur sé um að ræða samvinnu sem flestra í skólanum. Spillane (2006) bendir á að pannig geti forystan verið bæði formleg og óformleg. Hins vegar sé mikilvægt að forystan stuðli að menningu sem byggir á trausti og jákvæðum samskiptum (Alvesson, Jonsson, Sveningsson og Wenglén, 2015; Louise og Murphy, 2018).

Margs konar rannsóknir benda til pess að lærdómssamfélag skóla hafi áhrif á árangur nemenda. Detta má sjá bæði í jákvæðum áhrifum á pekkingu og hæfni nemenda og viðhorfum kennara (Anna Kristín Sigurðardóttir, 2010; Burns o.fl., 2017; Dogan og Adams, 2018; Lomos, Hofman og Bosker, 2011). Dó hefur verið bent á að mörgum spurningum sé enn ósvarað bæði um tengsl lærdómssamfélags í skólum við árangur í einstökum námsgreinum og aðra pætti skólastarfsins (Hairon, Goh, Chua og Wang, 2017; Lomos o.fl., 2011). Í ljósi pess er áríðandi að grandskoða mælingar á áhrifum lærdómssamfélags pví í peim liggja forsendurnar sem niðurstöđur byggja á og nýta á til að taka ákvarðanir um umbætur. Hairon og félagar (2017) nefna prennt sem kann að draga úr áreiðanleika rannsókna sem beinast að mikilvægi lærdómssamfélags fyrir árangur. Í fyrsta lagi er kenningalegur grunnur fremur veikur og skýrist meðal annars af flóknu samspili peirra hugtaka (sviða) sem byggja upp faglegt lærdómssamfélag, p.e. námi, samfélagi og fagmennsku. Í öðru lagi er erfitt að meta flókið samspil og áhrif pessara sviða á skólastarf eða árangur nemenda. Í priðja lagi geta ytri aðstæður skólans haft áhrif en eru oftast undanskildar í slíkum mælingum. Hairon o.fl. (2017) leggja pví til að rannsóknir á lærdómssamfélagi innan skóla nái yfir a.m.k. prjár víddir, sem eru: Eðli og einkenni faglegs lærdómssamfélags, aðstæður innan og utan skólans og loks möguleg áhrif á skólastarf og nám nemenda. Undir pessa gagnrýni taka Burns o.fl. (2017) og benda á ákveðna hættu sem getur fylgt pví að nota of miklar einfaldanir til að lýsa svo flóknu fyrirbæri sem lærdómssamfélag er.

\section{Mælingar á stöðu lærdómssamfélags í skólum}

próuð hafa verið mörg mælitæki til að meta megineinkenni lærdómssamfélags í skólum en birt hefur verið yfirlit um 49 slík mælitæki sem hafa verið notuð í Bandaríkjunum, 31 megindlegt og 18 eigindleg (Blitz og Schulman, 2016). Dau eru byggð upp á mismunandi hátt eftir pví hverjar áherslurnar eru og hvað á að mæla. Eitt pessara mælitækja (Olivier og Hipp, 2010) var sérstaklega hannað til að meta daglegt skólastarf út frá sex meginpáttum, sem eru: Dreifð og styðjandi forysta, sameiginleg gildi og sýn, sameiginlegt nám og starfspróun, miðlun eigin starfsreynslu til samstarfsfólks, styðjandi aðstæður - samskipti og styðjandi aðstæður - innra skipulag. Samanlagt eru staðhæfingar listans 52 talsins. Detta matstæki hefur verið notað sem umræðugrundvöllur í Háskólanum á Akureyri í vinnu með kennurum og skólastjórnendum í grunnskólum við próun faglegs lærdómssamfélags. Mælitækið sem slíkt var ekki lagt fyrir í skólum enda eru í pví atriði sem ekki eiga ekki við í íslenskum aðstæðum, t.d. spurningar um samstarf skóla og hagsmunaaðila (e. stakeholders). Dæmi um slíkar spurningar eru: „Hagsmunaaðilar líta svo á að peir beri sameiginlega ábyrgð á námi nemenda“ og „Starfsfólk skólans og hagsmunaaðilar eru samstíga í pví að láta vilja til skólapróunar einkenna menningu skólans“. Mælitækið hefur pví aðallega verið nýtt hérlendis með kennurum og stjórnendum grunnskóla við mótun sameiginlegs skilnings á merkingu hugtaka og útfærslu peirra innan skóla (Birna Svanbjörnsdóttir, 2015)

Sleegers, den Brok, Verbiest, Moolenaar og Daly (2013) unnu umfangsmikla greiningu á rannsóknum og fræðiskrifum um lærdómssamfélag í skólum í Hollandi. Pau bentu á að prátt fyrir vaxandi vinsældir lærdómssamfélags meðal rannsakenda, kennara og peirra sem móta mennta- 
stefnu væru upplýsingar um hugmyndafræðilegan grunn meginpátta lærdómssamfélags í skólum enn of veikburða. Úr greiningarvinnu peirra birtist flokkun á hæfni á premur sviðum sem pyrfti að vera til staðar (sjá mynd 1) eftir pví hvort hún sneri að einstaklingnum (hverjum kennara), að félagslegum páttum innan skólans eða hæfni stofnunarinnar sem heildar.

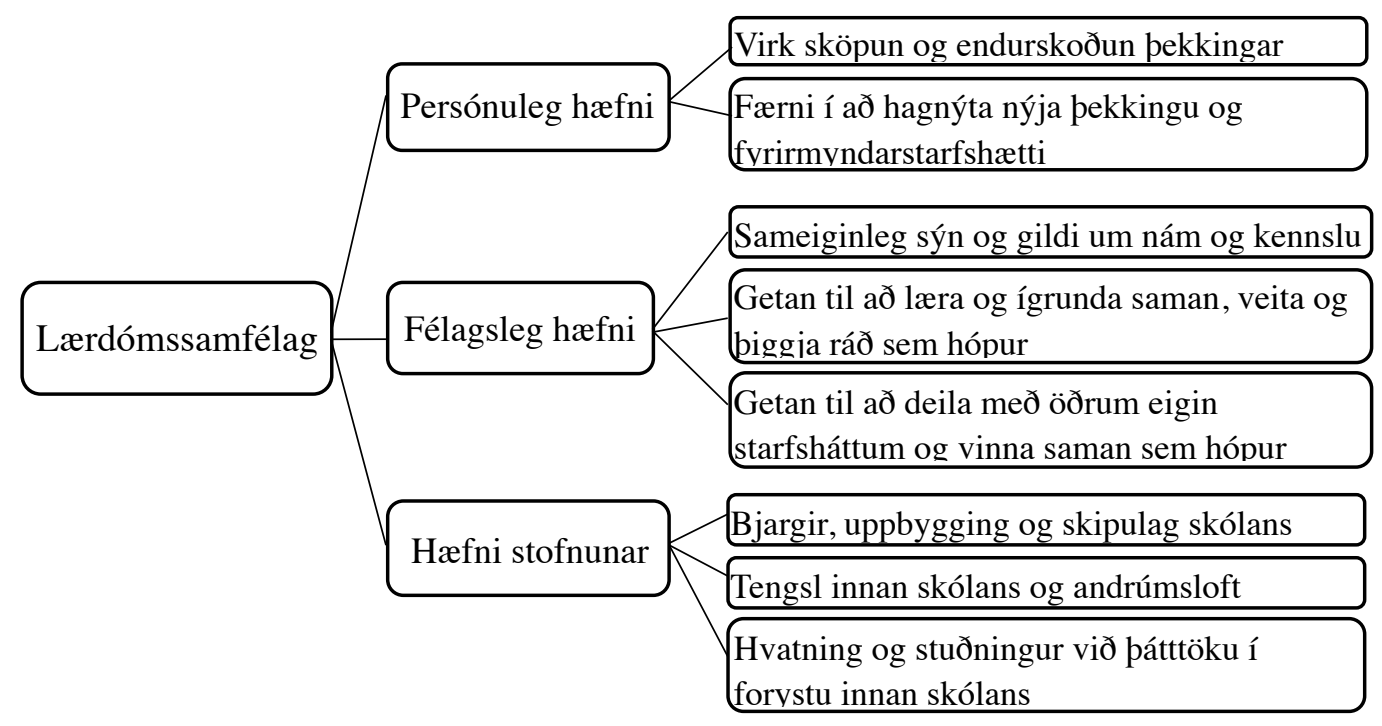

Mynd 1. Drjú hæfnisvið mælinga á lærdómssamfélagi í skólum (Sleegers o.fl., 2013, bls. 122).

Sleegers og félagar (2013) benda á að persónuleg hæfni einstaklinga hafi litla athygli fengið í rannsóknum á lærdómssamfélagi en sé samt sem áður mikilvægt svið sem taka purfi mið af. Dau útskýra að persónuleg hæfni hafi annars vegar verið mæld út frá hæfni einstaklingsins í virkri sköpun og endurskoðun pekkingar og hins vegar færni hans til að hagnýta nýja pekkingu í og með lærdómssamfélaginu, p.e. beita henni sem hluta af fyrirmyndarstarfsháttum. Félagsleg hæfni er annað svið sem Sleegers og félagar (2013) tilgreina að sé mikilvægt innan skóla. Pau rökstyðja að pessi hæfni hafi fengið töluverða athygli í rannsóknum á lærdómssamfélagi og að hún hefur verið mæld út frá sameiginlegri sýn og gildum hópsins um nám og kennslu, með sérstaka áherslu á að efla nám nemenda. Eins hefur geta hópsins til að læra og ígrunda saman og veita og piggja ráð hvert frá öðru verið greind sem einkenni lærdómssamfélags. Pá virðist geta hópsins til að deila með öðrum eigin starfsháttum og hæfni kennara til að vinna saman sem ein heild skipta máli. Hæfni skólans sem stofnunar er priðja svið lærdómssamfélags í skólum (Sleegers o.fl., 2013). Er pá átt við innra skipulag skólans og ytri ramma sem hafa víða komið fram sem mikilvæg atriði bæði í rannsóknum og fræðum. Undir hæfni skólans falla allar bjargir hans og hversu góðar pær eru en líka hvernig innri uppbygging og skipulag skólans er. Detta geta meðal annars verið skipulag á stundatöflu og vinnutíma kennara, aðgengi að upplýsingum og flæði upplýsinga. Tengsl innan skólans og andrúmsloftið hafa áhrif á hæfni skólans og hversu vel getur gengið að próa og viðhalda lærdómssamfélagi innan hans. Undir pennan pátt falla traust milli fólks, virðing og stuðningur milli starfsfólks, t.d. hreinskilni í samskiptum og hversu vel er tekið á móti nýjum starfsmönnum. Einnig hafa félagsleg tengsl fólks innan og utan vinnu og gæði starfsumhverfisins í heild hér áhrif. Pá benda Sleegers og félagar (2013) á að hvatning og stuðningur við pátttöku innan skólans sé páttur sem flestar rannsóknir hafa greint sem megineinkenni stofnana er hlúa að lærdómssamfélagi skóla. Í framhaldi mótuðu Sleegers og félagar (2013) spurningalista sem byggðist á pessari flokkun í prjú hæfnisvið lærdómssamfélags með átta páttum. Listinn var lagður fyrir í 76 hollenskum grunnskólum og fengust svör frá 992 kennurum (72\% svarhlutfall). Niðurstöður leiddu í ljós að hæfnisviðin prjú (með páttunum átta) komu skýrt fram í gögnunum sem aðgreindar einingar er lýsa inntaki lærdómssamfélags og meginpáttum pess. Byggt á pessum rannsóknarniðurstöðum vekja höfundar athygli á prennu. Í fyrsta lagi hvaða pættir leggja mest af 
mörkum (eru sterkastir) í hverju hæfnisviði. Dátturinn virk sköpun og endurskoðun pekkingar leggur mest af mörkum í hæfnisviðið persónuleg hæfni. Pátturinn sem lýsir getu hópsins til að læra og ígrunda saman og veita og piggja rád sem hópur leggi mest af mörkum í hæfnisviðið félagsleg hæfni og pátturinn tengsl innan skólans og andrúmsloft leggur mest af mörkum við að meta hæfni stofnunarinnar til að móta og próa lærdómssamfélag. Í öđru lagi bentu pau á að há jákvæð fylgni milli hæfnisviðanna priggja benti til pess að pau væru skýrt tengd. Í priðja lagi að aðgreining hugmynda um lærdómssamfélag í prjú hæfnisvið og átta pætti hefði komið skýrt í ljós bæði í spurningum um kennarana sjálfa og skólann í heild. Detta pýði að sameiginleg sýn (e. shared perception) á skólann annars vegar og munur sem fram kom á sýn einstaklinga á skólann hins vegar megi draga fram með spurningum á öllum hæfnisviðinum premur og páttunum átta (Sleegers o.fl., 2013).

Burns og félagar (2017) rannsökuðu stöðu lærdómssamfélags í rúmlega 180 skólum í einu fylki Bandaríkjanna par sem unnið hafði verið að skipulegri innleiðingu pess í prjú ár. Rannsóknin byggði á greiningu megindlegra gagna, m.a. til að skoða hverjir væru meginpættir lærdómssamfélags í skólum og tengsl peirra við árangur nemenda. Annars vegar var notuð áttskipt flokkun 46 atriða sem liggja til grundvallar sjálfsmati skóla í fylkinu á stöðu lærdómssamfélags. Hins vegar voru notaðar niðurstöður um árangur nemenda í námsgreinum. Niðurstöður leiddu í ljós að atriðin 46 greindust í tvo meginpætti; annars vegar samstarfs- og forystuferla (20 atriði) og hins vegar rýni byggða á gögnum (e. data-driven systems for learning) (26 atriði). Fylgni var milli flokkanna átta og árangurs nemenda, sérstaklega í stærðfræði yngri barna. Dá skoruðu skólarnir yfirleitt allnokkuð hærra á pættinum um samstarfs- og forystuferla, en pættinum um rýni byggða á gögnum.

Dogan og Adams (2018) greindu niðurstöður 13 alpjóðlegra rannsókna á lærdómssamfélagi í skólum. Deir benda líka á að pað sem helst virðist hafa batnað í starfsháttum kennara við próun lærdómssamfélags, er að peir reyni markvisst að nota aðferðir sem krefjast virkni nemenda og samstarfs peirra á milli, nota meiri upplýsingatækni í eigin störfum og beita frekar leiðsagnamati. Megináhrifin á nám nemenda birtust aðallega í lestri, tungumálanámi og stærðfræði. Í viðtalsgögnum og rýni í skrif nemenda birtust dæmi um breyttar áherslur á hegðun nemenda og viðhorf, ásamt aukinni einbeitingu. Á grundvelli niðurstaðna sinna settu Dogan og Adams (2018) fram líkan með fimm páttum lærdómssamfélags í skólum (sjá mynd 2). Allir pættirnir nema ígrundandi samræða hafa áhrif á nám nemenda og allir pættirnir hafa áhrif á kennsluhætti kennara.

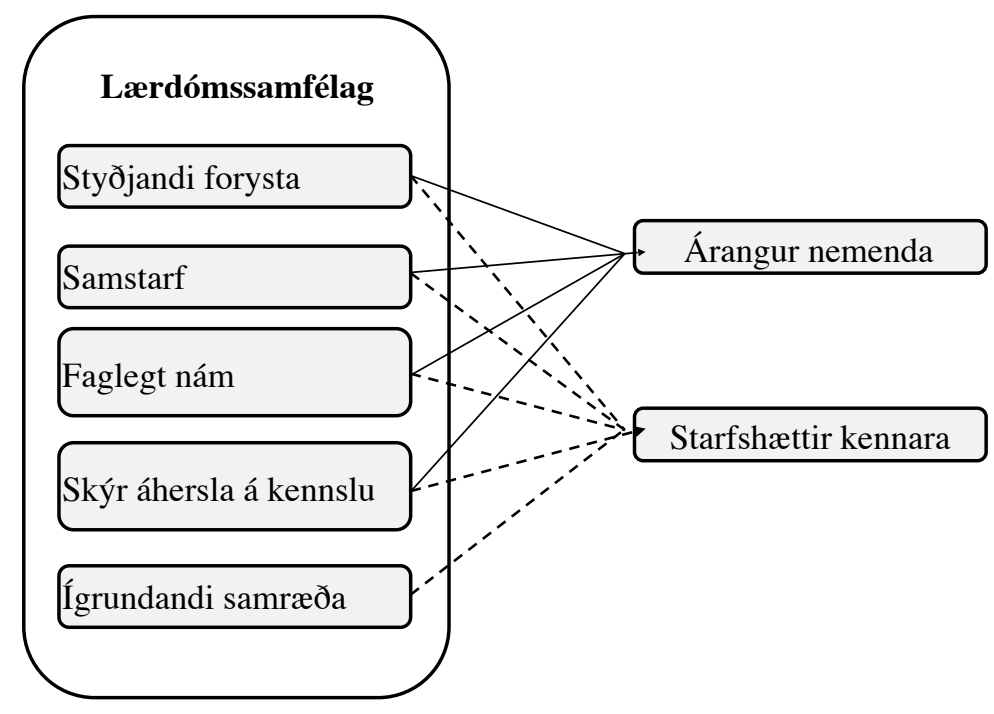

Mynd 2. Áhrif lærdómssamfélags í skólum á kennsluhætti kennara og nám nemenda (Dogan og Adams, 2018, bls. 18). 
Dogan og Adams (2018) benda pó jafnframt á að spurningunni um tengsl kennsluhátta og árangurs nemenda sé enn ósvarað og kalli pað á frekari rannsóknir pess efnis.

Líkt og erlendis hefur sjónum á Íslandi í vaxandi mæli verið beint að mótun og próun lærdómssamfélags í skólum. Anna Kristín Sigurðardóttir (2010) skoðaði tengsl lærdómssamfélags í grunnskólum með hliðsjón af árangri nemenda. Lagðir voru spurningalistar fyrir í premur íslenskum grunnskólum sem voru valdir með hliðsjón af námsárangri á samræmdum prófum í stærðfræði og íslensku í 10. bekk eftir að búið var að stjórna fyrir menntunarstigi foreldra og árangri nemenda við upphaf skólagöngu (e. value added scores). Spurningarnar voru byggðar á niðurstöðum rannsókna um lærdómssamfélag og próun pess. Niðurstöður leiddu í ljós átta pætti sem eru (1) sameiginleg sýn og gildi með áherslu á nám nemenda, (2) dreifð forysta, (3) gagnkvæmur stuðningur, (4) sameiginlegt nám með áherslu á parfir nemenda, (5) skipulag stofnunar sem styður við samstarf, (6) vinnuvenjur sem styðja við samstarf, (7) félagslegt andrúmsloft sem styður við samstarf og (8) ánægja með starfið í skólanum. Niðurstöðurnar bentu til að spurningar í fyrstu tveimur páttunum legðu mest af mörkum til stöðu lærdómssamfélags í skólunum. Pá komu fram skýrar vísbendingar um að tengsl væru milli pess hve sterk einkenni lærdómssamfélags væru í skólunum og pess hve skilvirkir peir væru.

Auður Pálsdóttur (2014) próaði mælitæki til að kortleggja hvaða innri og ytri pættir hefðu áhrif á getu einstakra skóla til að vinna með og innleiða ný námssvið aðalnámskrár. Markmiðið var að finna vísbendingar um að hverju samræður og aðgerðir starfsfólks innan skólans pyrftu að beinast (Stewart og Prebble, 1993), en ekki að móta tæki fyrir ytri úttektaraðila. Próaður var spurningalisti sem byggðist annars vegar á tveggja ára reynslu íslenskra kennara um hvað hindraði og hvað styddi innleiðingu nýjunga úr námskrá og hins vegar á greiningu fræða og prófunum á spurningum sem gæfu upplýsingar um núverandi stöðu í skólanum og hver gætu verið næstu skref í skólapróun. Î lok greiningarvinnu var spurningalisti lagður fyrir 276 pátttakendur í 12 skólum á Íslandi. Niðurstöður leiddu í ljós fimm pætti með samtals 51 staðhæfingu sem gáfu mynd af stöðu skólans og greindu prír peirra (nr. 1, 2 og 4) með marktækum hætti á milli skóla. Pættirnir eru (1) samstarf og endurgjöf innan skóla, (2) aðstæður innan skóla, stjórnun og stuðningur, (3) sýn á námssviðið í mótun, (4) trú kennara á getu hópsins í próunarstarfi (e. collective teacher efficacy) og (5) hversu tilbúinn hópurinn er til að vinna með nýja námssviðið.

Að framansögðu má álykta að til mikils er að vinna við að styrkja lærdómsamfélag skóla, par sem vísbendingar eru um jákvæð áhrif á faglegt nám kennara og árangur nemenda. Dað er pví fengur að pví að fá mælitæki sem nýtist við íslenskar aðstæður. Við mótun mælitækisins var fyrst og fremst byggt á peim mælitækjum sem höfðu pegar verið próuð og nýtt hér á landi en pau mótuð og aðlöguð að nýrri erlendum rannsóknum eins og Dogan og Adams (2018) og Sleegers o.fl. (2013).

\section{Aðferð}

\section{Pátttakendur}

Dátttakendur rannsóknarinnar voru starfsfólk grunnskóla í tveimur sveitarfélögum á Íslandi. Alls tóku 14 grunnskólar pátt, átta í Hafnarfirði og sex í Akureyrarbæ. Eftir að sampykki hafði fengist hjá fræðsluyfirvöldum bæjarfélaganna tveggja var spurningalisti sendur rafrænt til allra kennara og skólastjórnenda pátttökuskólanna vorið 2018. Alls svöruðu spurningalistanum 203 kennarar, 45 skólastjórnendur (skólastjóri, aðstoðarskólastjóri eða deildarstjóri) og 16 pátttakendur með aðra fagmenntun, svo sem námsráðgjafar eða sérkennarar, auk pess sem 11 pátttakendur gáfu ekki upp hvert aðalstarfssvið peirra var. Alls fengust gild svör frá 273 pátttakendum og var svarhlutfallið $43 \%$. 


\section{Mælitæki}

Markmið rannsóknarinnar er að próa mælitæki til pess að meta stöðu lærdómssamfélagsins innan skóla. Rannsóknin var hluti af stærra rannsóknarverkefni sem ber heitið „,Að bera meira út býtum“ (BMB). Spurningalistinn sem var notaður í rannsókninni var upphaflega byggður á listum Önnu Kristínar Sigurðardóttur (2006) og Auðar Pálsdóttur (2014) sem beindust sérstaklega að íslenskum aðstæðum auk pess að stuðst var við lista Olivier og Hipp (2010) sem notaður hafði verið við Háskólann á Akureyri í starfi með kennurum og stjórnendum grunnskóla. Alls voru mótaðar 64 staðhæfingar sem ætlað var að meta stöðu lærdómssamfélagsins innan skóla. Staðhæfingarnar tengdust: (1) forystu, dæmi um slíkar staðhæfingar eru „Skólastjórnendur sýna kennslu minni áhuga“ og „Í pessum skóla er lögð áhersla á að styðja við og hvetja til pess að starfsfólk taki forystu“; (2) sameiginlegum gildum, dæmi: ,Í pessum skóla er skýrt hver sé stefna og áherslur skólans í námi og kennslu“; (3) miðlun reynslu, dæmi: „Kennarar í pessum skóla segja hver öðrum frá aðferðum sem hafa reynst vel í kennslu“ og „Kennarar í pessum skóla fá handleiðslu og leiðsögn í starfi“; (4) faglegum aðstæðum, dæmi: „Kennarar við pennan skóla eru viljugir til samstarfs innan skólans“ og „Ég hef aðgang að nauðsynlegum kennslugögnum og tækjum sem ég parf til að próast sem fagmaður“; (5) nemendum, dæmi: „Kennsluaðferðir mínar ráða miklu um hvort nemendur ná árangri“ og „Raunveruleg geta nemenda kemur skýrt fram í námsárangri peirra“; og að lokum (6) starfsánægju, dæmi: „Mér líður vel í vinnunni“ og „Ég er stolt(ur) af pví að starfa í pessum skóla“. Hver staðhæfing var mæld á 6 punkta Likert-kvarða: ,,algjörlega ósammála“, „,mjög ósammála“, „, frekar ósammála“, „, frekar sammála“, „,mjög sammála“ og ,,algjörlega sammála“. Gildi á hverri staðhæfingu var kóðað fá 0 upp í 5 par sem hærra gildi gaf til kynna aukna samsvörun við staðhæfinguna. Ásamt staðhæfingum tengdum lærdómssamfélaginu var spurt um bakgrunnspætti eins og starfsreynslu, starfssvið (kennari /stjórnandi/annað) og á hvaða aldursstigi væri (aðallega) kennt.

\section{Framkvæmd}

Spurningalistinn sem lagður var fyrir í pessari rannsókn byggir á spurningalista sem var unninn og forprófaður vorið 2017 í 13 grunnskólum á höfuðborgarsvæðinu og Suðurlandi sem voru pátttökuskólar í rannsóknarverkefninu BMB. Eftir forprófun unnu prír sérfræðingar frá Menntavísindasviði Háskóla Íslands og einn frá Háskólanum á Akureyri að endurskoðun listans. Endurskoðun fólst bæði í tölfræðilegri greiningu á svörum auk pess sem fræðilegt innihald listans var endurmetið. Endurskoðun leiddi af sér spurningalista með 64 staðhæfingum sem ætlað var að meta stöðu lærdómssamfélagsins út frá páttunum sem tengdust (1) dreifðri og styðjandi forystu, (2) sameiginlegum gildum og sýn, (3) sameiginlegu námi og starfspróun, (4) miðlun reynslu og endurgjafar til samstarfsfólks, (5) styðjandi aðstæðum fyrir samskipti og skipulag, (6) væntingum um árangur nemenda og (7) starfsánægju. Degar endurskoðun listans var lokið var hann lagður fyrir á ný í tveimur sveitarfélögum, Akureyrarbæ og Hafnarfirði, með áframhaldandi próun spurningalistans að markmiði. Listinn var sendur rafrænt í gegnum Qualtrics-hugbúnaðinn til allra kennara og stjórnenda í 14 grunnskólum sveitarfélaganna tveggja vorið 2018. Deim sem tóku pátt var boðið að skrá netfang sitt í happdrætti sem gaf tækifæri á að vinna 10 púsund króna gjafabréf. Var petta gert í peim tilgangi að auka svarhlutfall. Að lokinni fyrirlögn voru niðurstöður greindar með pað fyrir augum að hámarka áreiðanleika og réttmæti listans.

\section{Gagnagreining}

Rannsóknin byggist á megindlegu rannsóknarsniði til að próa mælitæki í formi spurningalista sem notað er til að meta lærdómssamfélag innan skóla. Tölfræðiforritið Mplus var notað við greiningu gagnanna. Leitandi páttagreiningu með hornskökkum snúningi (e. direct oblimin) var beitt sem leyfir fylgni milli pátta. Með pví að leyfa fylgni milli pátta fæst auðtúlkanlegra páttalíkan par sem gera mátti ráð fyrir pví að samband væri milli pátta sem mynda lærdómssamfélag (Brown, 2015). Dau mælitæki sem liggja hér til grundvallar hafa sýnt að pættir lærdómssamfélagsins eru tengdir innbyrðis (Anna Kristín Sigurðardóttir, 2006; Oliver og Hipp, 2010; Auður Pálsdóttir, 2014). 
Til pess að ákvarða fjölda pátta var samhliðagreining Horns notuð en færð hafa verið rök fyrir áreiðanleika peirrar aðferðar umfram aðrar aðferðir (Zwick og Velicer, 1986). Innra samræmi páttanna var metið með stuðlinum Cronbachs alfa og reyndust gildi allra páttanna vera vel yfir viðmiðunarmörkunum.

Aðferðin FIML (Full Information Maximum Likelihood) var notuð við meðhöndlun brottfallsgilda, en hún pykir traust og er sjálfgild stilling í tölfræðiforritinu Mplus pegar notuð er reikniaðgerðin MLR. Valið var að nota pá aðferð umfram færslubundna frávísun (e. listwise) par sem fjöldi brottfallsgilda var $>5 \%$ og ekki er ráðlegt að nota paraða frávísun (e. pairwise) par sem ekki var fyllilega hægt að færa rök fyrir pví að brottfallsgildi væru tilviljunarkennd í gögnunum (Schreiber, Nora, Stage, Barlow og King, 2006).

Dreifing gagnanna sýndi að gildi skekkju og ferilriss breytanna var innan ásættanlegra marka \pm 2 (George og Mallery, 2010) að undanskildum tveimur breytum sem höfðu jákvæða skekkju $>2$.

\section{Niðurstöður}

Beitt var leitandi páttagreiningu á 64 breytur. Samhliðagreining Horns leiddi í ljós að velja ætti 6 pátta lausn. Pær breytur sem höfðu páttahleðslu hærri en 0,4 á einn af pessum sex páttum, auk pess að hlaðast ekki tiltölulega jafnt á tvo pætti, var haldið í líkaninu. Niðurstöður sýndu að 34 breytur hlóðust á sex pætti með vogtölur hærri en 0,4. Í töflu 1 má sjá páttalíkanið par sem 34 staðhæfingar hlóðust á pættina sex. Pættirnir sex sem sýndu sig í líkaninu voru (I) sameiginleg sýn og gildi, (II) gagnrýnin ígrundun eigin kennslu, (III) faglegur stuðningur við próun kennsluhátta, (IV) dreifð og styðjandi forysta, (V) félagslegt andrúmsloft styður samstarf og (VI) starfsánægja. Innri áreiðanleikastuðullinn Cronbachs alfa reyndist vera hár fyrir alla pættina sex (lægst $0,82$ og hæst 0,93$)$ og var pví vel yfir lágmarksviðmiðunarmarki. Alfastuðulinn fyrir hvern pátt má sjá í töflu 1. Í töflu 1 má einnig sjá páttaskýringu (h2) staðhæfinganna og sést að páttaskýring var á bilinu 33-85\% með meðalpáttaskýringu 62\%.

Tafla 1. Mynsturfylki fyrir sex pátta líkan í leitandi páttagreiningu mestu líkinda (MLR)^

\begin{tabular}{|c|c|c|c|c|c|c|c|}
\hline & DI & DII & DIII & DIV & DV & Dvi & $h^{2}$ \\
\hline \multicolumn{8}{|l|}{ I Sameiginleg sýn og gildi } \\
\hline $\begin{array}{l}\text { Í pessum skóla eru ákvarðanir teknar með } \\
\text { hliðsjón af sameiginlegum gildum og stefnu } \\
\text { skólans. }\end{array}$ & 0,89 & 0,05 & 0,00 & $-0,01$ & $-0,01$ & 0,05 & 0,85 \\
\hline $\begin{array}{l}\text { Í pessum skóla byggja áætlanir um skólapró- } \\
\text { un á sameiginlegum gildum og stefnu skól- } \\
\text { ans. }\end{array}$ & 0,87 & 0,02 & 0,06 & 0,06 & $-0,03$ & $-0,02$ & 0,84 \\
\hline $\begin{array}{l}\text { Stefna og áherslur skólans eru sýnilegar í } \\
\text { daglegu starfi mínu með nemendum. }\end{array}$ & 0,72 & 0,05 & 0,11 & $-0,14$ & 0,07 & 0,01 & 0,57 \\
\hline $\begin{array}{l}\text { Í pessum skóla er skýrt hver sé stefna og } \\
\text { áherslur skólans í námi og kennslu. }\end{array}$ & 0,72 & 0,06 & $-0,04$ & 0,10 & 0,02 & 0,08 & 0,72 \\
\hline $\begin{array}{l}\text { Stjórnendur skólans eru samstíga um á hvað } \\
\text { beri að leggja áherslu í skólastarfinu. }\end{array}$ & 0,64 & $-0,03$ & $-0,61$ & 0,12 & 0,12 & 0,14 & 0,62 \\
\hline $\begin{array}{l}\text { Í stefnu skólans er skýr áhersla á að efla gæði } \\
\text { náms allra nemenda. }\end{array}$ & 0,56 & 0,10 & 0,08 & 0,05 & $-0,05$ & 0,15 & 0,56 \\
\hline $\begin{array}{l}\text { Kennarar í pessum skóla taka pátt í umræðu } \\
\text { um framtíðarsýn og áherslur skólans. }\end{array}$ & 0,47 & 0,18 & 0,11 & 0,22 & 0,09 & $-0,03$ & 0,62 \\
\hline \multicolumn{8}{|c|}{ Cronbachs alfa áreiðanleikastuðull páttarins $=\mathbf{0 , 9 3}$} \\
\hline
\end{tabular}




\section{Gagnrýnin ígrundun eigin kennslu}

Kennarar í pessum skóla rýna saman í gögn/ $\quad \begin{array}{llllllll}0,01 & \mathbf{0 , 8 7} & 0,01 & -0,03 & 0,05 & 0,06 & 0,83\end{array}$ upplýsingar til að meta eigin kennslu.

$\begin{array}{lllllllll}\text { Kennarar í pessum skóla rýna skipulega } & 0,18 & \mathbf{0 , 7 1} & 0,10 & -0,06 & -0,02 & 0,08 & 0,72\end{array}$ saman í niðurstöđur námsmats.

$\begin{array}{llllllll}\text { Kennarar skólans skipuleggja og vinna saman } & 0,04 & \mathbf{0 , 6 2} & 0,14 & 0,02 & 0,10 & 0,02 & 0,59\end{array}$ að pví að leita leiða til að mæta mismunandi pörfum nemenda.

Cronbachs alfa áreiðanleikastuðull páttarins $=\mathbf{0 , 8 9}$

\section{Faglegur stuðningur við próun kennsluhátta}

Ég prófa pað sem ég læri af samkennurum $0,00 \quad 0,0$ mínum í minni kennslu.

Ég ræði reglulega við samkennara mína um $\begin{array}{rlllllll}-0,02 & 0,10 & \mathbf{0 , 7 3} & 0,08 & -0,09 & 0,00 & 0,68\end{array}$ hvaða aðferðir séu árangursríkastar til að kenna fagið / árganginum.

Ég fæ góðan stuðning frá samkennurum $\begin{array}{llllllll}0,07 & 0,14 & \mathbf{0 , 5 3} & -0,04 & 0,08 & 0,06 & 0,47\end{array}$ pegar ég vil breyta kennsluaðferðum mínum.

$\begin{array}{lllllllll}\text { Ég get reitt mig á aðstoð samstarfsmanna } & 0,17 & -0,07 & \mathbf{0 , 4 7} & -0,10 & 0,26 & 0,10 & 0,47\end{array}$ minna hvenær sem er pótt pað sé ekki skilgreindur hluti af peirra starfssviði.

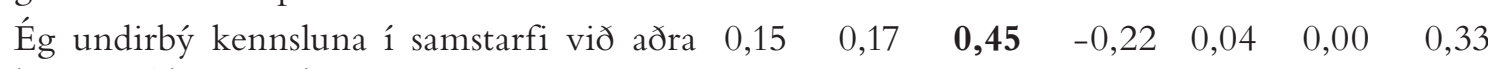
kennara í hverri viku.

Samkennarar mínir kunna að meta pað sem $\begin{array}{llllllll}-0,08 & 0,05 & \mathbf{0 , 4 4} & 0,05 & 0,32 & 0,11 & 0,49\end{array}$ ég hef fram að færa í samstarfi.

$\begin{array}{llllllll}\text { Kennarar í pessum skóla deila hugmyndum } & -0,08 & 0,18 & \mathbf{0 , 4 3} & 0,22 & 0,26 & 0,01 & 0,58\end{array}$ um aðferðir til að styrkja góða hegðun nemenda.

Cronbachs alfa áreiðanleikastuðull páttarins $=\mathbf{0 , 8 5}$

\section{Dreifð og styðjandi forysta}

$\begin{array}{llllllll}\text { Skólastjórinn tekur eftir pví pegar ég vinn } & 0,09 & 0,11 & -0,01 & \mathbf{0 , 6 1} & -0,02 & 0,21 & 0,67\end{array}$ vel og læu pað í ljósi.

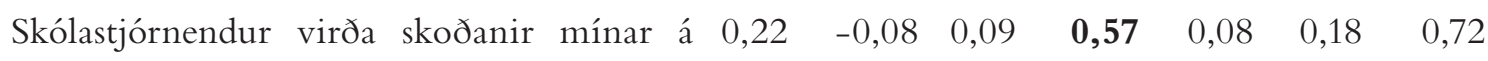
starfinu.

$\begin{array}{llllllll}\text { Ég fæ góðan stuðning frá stjórnendum pegar } & 0,08 & -0,08 & 0,20 & \mathbf{0 , 5 6} & 0,10 & 0,17 & 0,63\end{array}$ ég vil breyta kennsluaðferðum mínum.

Ég fær reglulega endurgjöf í skólanum um $\begin{array}{rlllllll}-0,10 & 0,44 & 0,07 & \mathbf{0 , 5 4} & 0,04 & 0,03 & 0,66\end{array}$ hvernig ég get bætt kennsluna mína.

Stjórnendur skólans leita oft eftir áliti starfs- $\begin{array}{llllllll}0,34 & -0,10 & 0,09 & \mathbf{0 , 5 2} & 0,10 & -0,04 & 0,60\end{array}$ fólks áđur en peir taka veigamiklar ákvarð-

anir.

$\begin{array}{llllllll}\text { Skólastjórnandi fylgist reglulega með kennslu } & 0,04 & 0,39 & -0,09 & \mathbf{0 , 5 1} & 0,05 & -0,06 & 0,53\end{array}$ minni (a.m.k. einu sinni í mánuði).

Í pessum skóla er lögð áhersla á að styðja við $\begin{array}{lllllll}0,35 & 0,01 & 0,05 & \mathbf{0 , 5 0} & 0,02 & 0,12 & 0,71\end{array}$ og hvetja til pess að starfsfólk taki forystu.

$\begin{array}{llllllll}\text { Ég fæ tækifæri til að taka pátt í ákvörðunum } & 0,20 & -0,07 & 0,17 & \mathbf{0 , 4 7} & 0,00 & 0,20 & 0,59\end{array}$ sem hafa áhrif á starf mitt.

Cronbachs alfa áreiðanleikastuðull páttarins $=\mathbf{0 , 9 2}$ 


\begin{tabular}{|c|c|c|c|c|c|c|c|}
\hline \multicolumn{8}{|l|}{ V Félagslegt andrúmsloft styður samstarf } \\
\hline $\begin{array}{l}\text { Kennarar leysa farsællega ágreiningsmál sín } \\
\text { á milli. }\end{array}$ & $-0,04$ & 0,01 & $-0,14$ & 0,03 & 0,84 & $-0,02$ & 0,62 \\
\hline $\begin{array}{l}\text { Kennarar við pennan skóla eru viljugir til } \\
\text { samstarfs innan skólans. }\end{array}$ & 0,05 & 0,02 & 0,13 & $-0,06$ & 0,78 & $-0,01$ & 0,73 \\
\hline $\begin{array}{l}\text { Kennarar skólans hafa pá getu sem parf til að } \\
\text { sinna starfinu vel. }\end{array}$ & 0,02 & $-0,02$ & 0,09 & $-0,02$ & 0,71 & $-0,01$ & 0,55 \\
\hline $\begin{array}{l}\text { Ég get hugsað mér að vera í samstarfi við } \\
\text { hvaða kennara sem er innan skólans. }\end{array}$ & $-0,07$ & 0,02 & $-0,13$ & $-0,05$ & 0,69 & 0,05 & 0,41 \\
\hline $\begin{array}{l}\text { Samskipti alls starfsfólks eru opin og heiðar- } \\
\text { leg og einkennast af gagnkvæmu trausti. }\end{array}$ & 0,08 & 0,10 & 0,01 & 0,19 & 0,51 & 0,12 & 0,57 \\
\hline Cronbachs alfa áreiðanleikastuðull pátta & rins $=0$ & & & & & & \\
\hline
\end{tabular}

\begin{tabular}{|c|c|c|c|c|c|c|c|}
\hline \multicolumn{8}{|l|}{ VI Starfsánægja } \\
\hline Mér líður vel í vinnunni. & $-0,09$ & 0,03 & 0,02 & 0,03 & $-0,05$ & 0,91 & 0,77 \\
\hline Ég er stolt(ur) af pví að starfa í pessum skóla. & 0,05 & 0,04 & $-0,07$ & 0,01 & 0,01 & 0,89 & 0,84 \\
\hline Nemendur skólans treysta kennurum sínum. & 0,12 & 0,04 & 0,10 & $-0,10$ & 0,01 & 0,57 & 0,45 \\
\hline $\begin{array}{l}\text { Mér líkar vel að kenna pá námsgrein / pví } \\
\text { aldursstigi sem ég kenni mest. }\end{array}$ & $-0,02$ & $-0,15$ & 0,09 & $-0,03$ & 0,07 & 0,54 & 0,33 \\
\hline Cronbachs alfa áreiðanleikastuðull pátta & rins $=0$ & 0,82 & & & & & \\
\hline
\end{tabular}

\begin{tabular}{cccccc} 
Páttafylgni & I & II & III & IV & V \\
\hline I & 1 & & & & \\
II & 0,39 & 1 & & & \\
III & 0,35 & 0,44 & 1 & & \\
IV & 0,54 & 0,33 & 0,28 & 1 & \\
V & 0,36 & 0,36 & 0,38 & 0,28 & 1 \\
VI & 0,55 & 0,28 & 0,35 & 0,37 & 0,39 \\
\hline
\end{tabular}

^Mynsturfylkin eru með oblimin hornskökkum snúningi. Taflan sýnir staðhæfingar með vogtölur 0,4 eða hærri á einn pátt.

Til pess að fá lýsandi tölfræði fyrir hvern pátt voru gildi spurninga innan hvers páttar lagðar saman í kvarða par sem hærra gildi gaf til kynna aukna samsvörun við páttinn. Í töflu 2 má sjá lýsandi upplýsingar um kvarða, meðaltöl, staðalfrávik og fjölda svara fyrir hvern pátt.

Tafla 2. Lýsandi tölfræði fyrir samanlögð gildi spurninga innan pátta.

\begin{tabular}{|c|c|c|c|c|c|c|c|}
\hline & Heiti & $\begin{array}{l}\text { Fjöldi } \\
\text { spurninga }\end{array}$ & $\mathbf{N}$ & Kvarði & $\mathbf{M}(\mathbf{S f})$ & $\begin{array}{l}\text { lægsta } \\
\text { gildi }\end{array}$ & $\begin{array}{l}\text { hæsta } \\
\text { gildi }\end{array}$ \\
\hline Páttur I & Sameiginleg sýn og gildi & 7 & 234 & 0 til 35 & $24,1(6,1)$ & 3 & 35 \\
\hline Páttur II & $\begin{array}{l}\text { Gagnrýnin ígrundun eigin } \\
\text { kennslu }\end{array}$ & 3 & 237 & 0 til 15 & $9,4(3,0)$ & 0 & 15 \\
\hline Dáttur III & $\begin{array}{l}\text { Faglegur stuðningur við } \\
\text { próun kennsluhátta }\end{array}$ & 7 & 211 & 0 til 35 & $25,5(5,5)$ & 7 & 35 \\
\hline Dáttur IV & Dreifð og styðjandi forysta & 8 & 208 & 0 til 40 & $22,4(8,6)$ & 0 & 40 \\
\hline Páttur V & $\begin{array}{l}\text { Félagslegt andrúmsloft } \\
\text { styður samstarf }\end{array}$ & 5 & 223 & 0 til 25 & $17,3(3,9)$ & 6 & 25 \\
\hline Páttur VI & Starfsánægja & 4 & 217 & 0 til 20 & $15,7(3,6)$ & 3 & 20 \\
\hline
\end{tabular}

$\mathrm{M}=$ meðaltal, $\mathrm{Sf}=$ staðalfrávik, $\mathrm{N}=$ fjöldi svara 
Í töflu 3 má sjá meðaltöl og staðalfrávik hvers páttar eftir pátttökuskólum.

Tafla 3. Meðaltöl og staðalfrávik pátta eftir skólum.

\begin{tabular}{ccccccc}
\hline & DI & DII & DIII & DIV & DV & DvI \\
Skóli & $\mathrm{M}(\mathrm{S} f)$ & $\mathrm{M}(\mathrm{Sf})$ & $\mathrm{M}(\mathrm{Sf})$ & $\mathrm{M}(\mathrm{Sf})$ & $\mathrm{M}(\mathrm{Sf})$ & $\mathrm{M}(\mathrm{Sf})$ \\
\hline S1 & $21,7(4,9)$ & $8,9(2,5)$ & $24,7(5,1)$ & $20,1(7,9)$ & $15,9(4,6)$ & $17,1(3,7)$ \\
S2 & $24,0(3,9)$ & $8,2(3,3)$ & $22,3(6,7)$ & $25,7(7,7)$ & $16,4(3,2)$ & $14,3(3,7)$ \\
S3 & $23,6(7,0)$ & $8,8(3,4)$ & $26,7(4,3)$ & $24,7(7,5)$ & $16,4(3,2)$ & $14,3(3,7)$ \\
S4 & $24,0(6,5)$ & $10,9(2,7)$ & $27,4(3,8)$ & $25,1(7,0)$ & $14,2(4,5)$ & $15,6(2,8)$ \\
S5 & $28,3(3,6)$ & $11,0(2,3)$ & $26,0(6,8)$ & $27,5(5,9)$ & $21,1(3,7)$ & $17,6(2,2)$ \\
S6 & $24,5(4,8)$ & $9,0(2,8$ & $26,1(4,7)$ & $21,7(7,6)$ & $16,8(3,9)$ & $16,0(2,5)$ \\
S7 & $33,6(1,7)$ & $12,2(2,9)$ & $27,5(5,7)$ & $33,0(4,4)$ & $22,5(2,3)$ & $18,3(1,3)$ \\
S8 & $24,7(4,8)$ & $8,7(3,4)$ & $25,2(6,7)$ & $22,2(8,1)$ & $16,6(2,9)$ & $16,1(2,6)$ \\
S9 & $27,7(3,4)$ & $10,4(2,6)$ & $27,4(4,6)$ & $27,6(6,3)$ & $17,7(3,4)$ & $16,4(2,1)$ \\
S10 & $26,7(6,6)$ & $9,3(3,2)$ & $27,7(5,9)$ & $22,2(10,5)$ & $17,8(4,3)$ & $17,9(1,9)$ \\
S11 & $23,3(4,3$ & $9,8(2,3)$ & $24,8(4,4)$ & $22,8(8,2)$ & $17,8(3,5)$ & $13,6(4,7)$ \\
S12 & $22,3(5,0)$ & $8,4(2,3)$ & $24,0(6,5)$ & $17,7(7,4)$ & $16,3(2,5)$ & $15,2(2,5)$ \\
S13 & $18,3(7,0)$ & $8,7(2,9)$ & $23,2(5,6)$ & $19,1(8,4)$ & $16,9(3,6)$ & $14,4(3,3)$ \\
S14 & $21,3(7,7)$ & $9,6(3,6)$ & $24,6(5,5)$ & $16,8(10,2)$ & $18,6(3,5)$ & $14,1(3,3)$ \\
\hline Alls: & $24,1(6,1)$ & $9,4(2,9)$ & $25,5(5,5)$ & $22,1(8,6)$ & $17,3(3,8)$ & $15,8(3,1)$ \\
\hline
\end{tabular}

Allsherjarprófi dreifigreiningar var beitt til að skoða nánar meðaltalsmun skóla. Í töflu 4 má sjá niðurstöður dreifigreiningar fyrir hvern af páttunum 6. Athugað var hvort pættirnir sem komu fram í páttagreiningu greindu á milli páttökuskóla pannig að marktækur munur reyndist á meðaltölum hæstu og lægstu skólanna á hverjum pætti. Í töflu 3 má sjá að marktækur munur var á meðaltölum einhverra pátttökuskóla á öllum páttum nema pætti III sem er „Faglegur stuðningur við próun kennsluhátta“.

Tafla 4. Allsherjarpróf dreifigreiningar fyrir meðaltalsmun pátta milli skóla.

\begin{tabular}{lccc}
\hline & $F$ & $P$ & $\eta 2$ \\
\hline (I) Sameiginleg sýn og gildi & 4,97 & $p<0,001$ & 0,24 \\
(II) Gagnrýnin ígrundun eigin kennslu & 1,80 & $p=0,041$ & 0,10 \\
(III) Faglegur stuðningur við próun kennsluhátta & 1,15 & $p=0,316$ & 0,08 \\
(IV) Dreifð og styðjandi forysta & 3,49 & $p<0,001$ & 0,20 \\
(V) Félagslegt andrúmsloft styður við samstarf & 3,28 & $p<0,001$ & 0,18 \\
(VI) Starfsánægja & 3,04 & $p<0,001$ & 0,17 \\
\hline
\end{tabular}

Taflan sýnir F-próf dreifigreiningar, $p$ - gildi ásamt áhrifastærðinni Eta squared (ๆ2)

\section{Umræða}

Markmið pessarar rannsóknar var tvípætt, annars vegar að draga fram pá pætti sem einkenna lærdómssamfélag 1 íslenskum skólum og hins vegar að próa mælitæki sem gefur upplýsingar um stöðu lærdómssamfélags innan hvers skóla. Niðurstöðurnar komu að mörgu leyti ekki á óvart. Fyrri rannsóknir hafa sýnt að fjöldi pátta sem lýsa einkennum lærdómssamfélags séu á bilinu tveir til átta, allt eftir pví hvernig pættirnir eru flokkaðir. bó má benda á að inntak páttanna er að mestu leyti ápekkt. Úr tölfræðigreiningu pessarar rannsóknar birtust sex skýrir pættir úr 34 fullyrðingum og ríma peir um flest vel við pað sem fram hefur komið í fyrri rannsóknum hérlendis 
sem og erlendis. Dættirnir sex sem fram komu í gögnunum eru (I) sameiginleg sýn og gildi, (II) gagnrýnin ígrundun eigin kennslu, (III) faglegur stuðningur við próun kennsluhátta, (IV) dreifð og styðjandi forysta, (V) félagslegt andrúmsloft styður samstarf og (VI) starfsánægja.

Einkum má benda á fimm efnisatriði sem vöktu athygli í niðurstöðunum. Í fyrsta lagi er pað hlutur gagna og upplýsinga í ákvarðanatöku í kennslu og öđru skólastarfi. Burns og félagar (2017) greindu pætti lærdómssamfélags í tvo meginpætti og bentu á að flestar hliðar lærdómssamfélags fyrri rannsókna hefðu fallið undir páttinn samstarfs- og forystuferlar. Seinni pátturinn, um að rýna í hlutverk og pátt gagna og upplýsinga við ákvarðanatöku í kennslu og öðru skólastarfi, væri hins vegar sjaldgæfari. Niðurstöður pessarar rannsóknar benda til svipaðrar niðurstöðu og kom fram hjá Burns og félögum (2017). Aðeins tvö atriði (í pætti II) komust inn á lokagerð listans og kallar pað á frekari rannsóknir á notkun gagna og upplýsinga kennara við ákvörðunartöku tengda kennsluháttum sínum.

Í öðru lagi var pað hlutur skipulagðrar endurgjafar í skólastarfinu. Í niðurstöðum má sjá að aðeins eitt atriði um endurgjöf er í lokagerð spurningalistans (birtist í pætti IV). Var sú niðurstaða pvert á væntingar en pó í samræmi við niðurstöður TALIS-rannsóknanna hér á landi (Ragnar F. Ólafsson, 2014, 2019). Kalla pessar niðurstöður á frekari rannsóknir um hvernig megi styðja kennara og stjórnendur við að veita og piggja skipulega endurgjöf um starfshætti sína í skólastarfinu og nýta pær upplýsingar við töku ákvarðana um skólastarfið.

Í priðja lagi virðast niðurstöður pessarar rannsóknar að nokkru leyti benda til að erfitt sé að greina hvort gagnrýnin ígrundun eigi sér stað meðal kennara. Aðeins prjú atriði mynda pátt II sem fékk heitið „Gagnrýnin ígrundun eigin kennslu“ og voru pað ákveðin vonbrigði. Kom pað pó ekki alveg á óvart pví prátt fyrir að ítrekað hafi verið bent á að gagnrýnin ígrundun og samræða (e. reflective dialogue) sé grundvallaratriði í mótun lærdómssamfélags hefur hún sjaldan náð inn í megindlegar rannsóknir, enda erfitt að mæla slíka samræðu með spurningalistum (Dogan og Adams, 2018; Hairon o.fl., 2017; Stoll o.fl., 2006; Vesco o.fl., 2008). Dessi niðurstaða er einnig samhljóma pví sem Anna Kristín Sigurðardóttir (2008) greindi pegar hún fylgdist með samræðu kennara á reglubundnum árgangafundum. Niðurstöður hennar bentu til að umræðan milli kennara bæri ekki einkenni gagnrýninnar ígrundunar og væri pví ekki líkleg til að leiða til lærdóms peirra sem pátt tóku.

Í fjórða lagi vakti athygli í niðurstöðum að starfsánægja birtist í pessum gögnum sem sérstakur páttur (nr. VI). Starfsánægju er ekki að finna í ofantöldum fyrri rannsóknum með eins afgerandi hætti og kemur hér fram sem vekur upp spurningar um hvort hér sé um eitthvað nýtt eða séríslenskt að ræða eða jafnvel hvort svipað megi greina annars staðar á Norðurlöndunum. Gefa pessar niðurstöður einnig tilefni til frekari rýni í hvað liggur að baki svörum kennara um líðan peirra og ánægju í starfi.

Í fimmta lagi er hér tekið undir gagnrýni Hairon og félaga (2017) um að pættir utan skólans verði oft út undan í rannsóknum á lærdómssamfélagi. Áhrif ytra umhverfis á starfshætti og menningu skóla hefur víða verið staðfest (t.d. Hoy og Miskel, 2013) en erfitt getur verið að greina áhrif peirra í einu mælitæki. Mælitækið sem hér er kynnt til sögunnar nær pví eingöngu til pátta innan skólans og er tilgangur pess að færa skólasamfélagi hvers skóla gögn sem par megi nýta til að rýna í starfið innan sinna skóla.

\section{Lokaord}

Í hnotskurn virðist mælitækið sem próað var í pessari rannsókn vera gott. Við páttagreiningu fengust sex skýrir pættir par sem innra samræmi hvers páttar fyrir sig var vel yfir viðmiðunarmörkum. Einnig var töluverður breytileiki í meðaltölum pátttökuskóla sem gefur til kynna að pættirnir greini á milli skóla. Đó ber að benda á að svarhlutfall í pessari rannsókn var ekki hátt svo taka ætti niðurstöðum um hvern skóla með fyrirvara. Í pví samhengi væri æskilegt að vinna 
áfram með mælitækið til pess að mögulegt væri að staðfesta gildi pess fyrir mat á lærdómssamfélagi skóla. Til pess parf frekari rannsóknir með aðkomu fleiri skóla og góðu svarhlutfalli innan einstakra skóla.

Eins og hér hefur verið kynnt er pað bæði áskorun fyrir starfsfólk skóla að innleiða og viðhalda faglegu lærdómssamfélagi og ekki síst að byggja slíkt samfélag á hlutlægum gögnum og upplýsingum sem aflað er með skipulögðum hætti. Prátt fyrir talsverðar vinsældir og vísbendingar um jákvæð áhrif lærdómssamfélags innan hvers skóla virðist sem fáum skólum hafi tekist pað nema upp að ákveðnu marki (Fullan, 2016; Harris, 2013). Рað er von höfunda að petta mælitæki geti orðið starfsfólki skóla til aðstoðar við petta flókna verkefni, en einnig að draga fram á hvaða sviðum starfshópurinn purfi ráđgjafar og leiðsagnar með, í hvaða átt purfi að beina starfspróun innan skólans og pá hver séu næstu vænlegu skref í pá átt. Dessi listi er próaður fyrir grunnskólastigið en gæti auðveldlega verið grunnur að sambærilegu mælitæki fyrir önnur skólastig. Næstu skref eru pví að staðfesta (e. validate) listann með hliðsjón af pátttöku fleiri skóla annars vegar og hins vegar með eigindlegum viðtölum um sýn pátttakenda á hvort niðurstöður peirra skóla rími við upplifun peirra og reynslu af starfinu í skólanum.

\section{Professional learning communities in compulsory schools. Development of a measuring instrument.}

The aim of this study is twofold. First, to increase our understanding of factors that influence the development of a professional learning community (PLC) in an Icelandic context and, second, to develop a reliable instrument to measure the level of PLCs in Icelandic compulsory schools. The literature strongly suggests it is worthwhile for schools to develop PLCs since there are numerous indicators that a PLC positively affects students' academic outcomes and school teaching practices (Burns et al., 2017; Dogan \& Adams, 2018; Anna Kristín Sigurðardóttir, 2010). Furthermore, the most successful staff development takes place within a learning community in schools, based on inquiry orientated practice and professional collaboration (OECD, 2019). Several PLC instruments exist (e.g., Hord, 1997; Oliver \& Hipp, 2010; Sleegers et al., 2013) but only one instrument has been developed specifically to measure PLCs in the Icelandic context (Anna Kristín Sigurðardóttir, 2010). This was a small-scale survey and did not include the most recent components of PLC, such as the critical use of data. Therefore, there was a need for a measurement instrument that grasps all these critical components in an Icelandic context and reliably measures the level of PLCs within Icelandic schools. The goal was to provide the school community with information based on the views of teachers and school leaders regarding the standing of their own professional environment within schools. Such information is vital to the professional development of teachers and for a sustainable improvement of schools and thus for student learning.

Quantitative research methods were used to determine the validity and reliability of the measure for use with teachers and school leaders in Iceland. The development of the instrument was carried out in two steps. First, a pilot survey was conducted in the fall of 2016, when a questionnaire was sent to all teachers and leaders in 13 Icelandic schools. Next, experts evaluated the questionnaire, based on both the literature and on statistical analysis. The survey was then conducted for the second time with a revised version of the questionnaire in 14 schools in two municipalities with the aim of further developing the instrument. An exploratory factor analysis was conducted on the data in order to determine the dimensionality of the revised questionnaire. Statistical analysis resulted in an instrument with 34 statements contained in 6 dimensions. The underlying dimensions were (I) shared vision and values, (II) use of 
critical data to improve teaching, (III) mutual professional support for teaching and learning (IV) shared and supportive leadership, (V) social climate that supports collaboration and (VI) job satisfaction and engagement.

In the discussion, five thought-provoking topics from the findings are considered in light of the literature with considerations as to why some findings were surprising but others were not. Firstly, we discuss the role of data and systematic collection of information to support decision-making regarding daily practice in schools. Secondly, we discuss the role and use of feedback in schools and how to support teachers and school administrators in Icelandic schools in receiving and giving feedback about their work. Thirdly, we discuss the challenge of analysing reflective dialogue between teachers about their practice, since reflective dialogue is considered to be a vital part of a professional learning community within schools. Fourthly, we discuss the partly surprising appearance of job satisfaction as a well-defined and distinct factor in the results (factor IV). Finally, we discuss the argument of Hairon et al. (2017) regarding the difficulty of assessing the influence of out of school factors on a PLC but the instrument presented here only encompasses the influence of factors within the school. The next step in the development and use of the instrument is to further validate the measure with the participation of additional schools and use interviews that can capture participants' view of the results. If the results from participants own schools are consistent with their experience, this would support the validation of the instrument.

Keywords: Professional learning communities, measuring instrument, compulsory school.

\section{Um höfundana}

Berglind Gísladóttir (berglindg@hi.is) er lektor í kennslufræðum við Menntavísindasvið Háskóla Íslands. Hún lauk B.Ed.-gráđu frá Kennaraháskóla Íslands 2002, M.Ed.-gráđu í stærðfræðimenntun frá Háskólanum í Reykjavík árið 2007 og doktorsprófi í stærðfræðimenntun frá Columbia-háskóla í New York árið 2013. Rannsóknaráhugi Berglindar beinist að námslegum og félagslegum páttum sem hafa áhrif á námsárangur nemenda. Einnig beinist áhuginn að fagpekkingu kennara og próun skólastarfs.

Auður Pálsdóttir (audurp@hi.is) er lektor við Menntavísindasvið Háskóla Íslands. Hún lauk B.S.-gráđu í landfræði frá Háskóla Íslands 1991, B.Ed.-gráðu í grunnskólakennslu frá Kennaraháskóla Íslands 1993, M.Ed.-gráđu frá University of Aberdeen, Skotlandi 1996 og doktorsprófi í menntunarfræðum frá Háskóla Íslands 2014. Rannsóknarsvið hennar eru mat á skólastarfi og skólapróun, landfræðikennsla og kennslufræði náttúru- og samfélagsgreina, sjálfbærnimenntun, greining námsefnis og útikennsla.

Anna Kristín Sigurðardóttir (aks@hi.is) er prófessor við Menntavísindasvið Háskóla Íslands og formaður námsbrautar um menntastjórnun og matsfræði. Hún er með B.Ed.-gráðu í grunnskólakennslu og M.Ed.-gráðu frá Kennaraháskóla Íslands. Doktorsgráđu lauk hún frá Háskólanum í Exeter 2006 á sviði menntastjórnunar. Rannsóknarsvið hennar tengjast menntastjórnun, skólapróun, lærdómssamfélagi og námsumhverfi skóla og tengslum við kennsluhætti.

Birna María Svanbjörnsdóttir (birnas@unak.is) er lektor við kennaradeild Hug-og félagsvísindasviðs Háskólans á Akureyri. Hún lauk B.Ed.-prófi frá Kennaraháskóla Íslands 1988 og starfaði sem grunnskólakennari um árabil. Hún lauk M.Ed.-gráðu 
frá Háskólanum á Akureyri 2005 og doktorsprófi í menntunarfræðum frá Háskóla Íslands 2015. Helstu áherslur í rannsóknum hennar lúta að starfspróun kennara, starfstengdri leiðsögn ásamt uppbyggingu og próun faglegs lærdómssamfélags.

\section{About the authors}

Berglind Gísladóttir (berglindg@hi.is) is an assistant professor in the Faculty of Subject Teacher Education at the School of Education, University of Iceland. She completed a B.Ed. from the University of Iceland in 2002, an M.Ed. in mathematics education from Reykjavík University in 2007 and a Ph.D. in mathematics education from Columbia University in New York in 2013. Her main research interests are educational and social factors that affect student achievement and teacher proficiency.

Auður Pálsdóttir (audurp@hi.is) is an assistant professor at the University of Iceland, School of Education. She holds a B.Sc. degree in geography since 1991, a B.Ed. degree in compulsory school teaching since 1993, an M.Ed. degree from University of Aberdeen in Scotland since 1996, and a Ph.D. in educational sciences from the University of Iceland since 2014. Her research interests are school self-evaluation and school development, teaching geography and pedagogy of science and social science studies, sustainability education, textbook analysis and outdoor education.

Anna Kristín Sigurðardóttir (aks@hi.is) is a professor in educational leadership in the School of Education, University of Iceland, and is the coordinator for the programme in educational leadership. She holds a B.Ed. and an M.Ed. in special education from Iceland University of Education. Her Ph.D. is from the University of Exeter, in educational leadership. Her research interests include educational leadership, school development, the professional learning community and a physical learning environment in relation to educational practices.

Birna María B. Svanbjörnsdóttir (birnas@unak.is) is an assistant professor in the Faculty of Education at the University of Akureyri. She graduated with a B.Ed. degree in compulsory school education in 1988 and has a long teaching career. Birna completed a master's degree from the University of Akureyri in 2005 and a Ph.D. in educational sciences from the University of Iceland 2015. Her main fields of research emphasis are teacher development, mentoring and professional learning communities.

\section{Heimildir}

Alvesson, M., Jonsson, A., Sveningsson, S. og Wenglén, R. (2015). När ledarskapet krackelerar. Insikter från den inte så lätta praktiken. Lund: Studentlitteratur.

Anna Kristín Sigurðardóttir. (2006). Studying and enhancing the professional learning community for school effectiveness in Iceland (doktorsritgerð). University of Exeter, Exeter.

Anna Kristín Sigurðardóttir. (2008). Faglegt samstarf kennara. Glœður, 18, $13-19$.

Anna Kristín Sigurðardóttir. (2010). Professional learning community in relation to school effectiveness. Scandinavian Journal of Educational Research, 54(5), 395-412. doi:10.1080/00313831.2010.508904

Anna Kristín Sigurðardóttir. (2013). Skóli sem lærdómssamfélag. Í Rúnar Sigpórsson, Rósa Eggertsdóttir og Guðmundur Heiðar Frímannsson (ritstjórar), Fagmennska í skólastarfi. Skrifað til heiðurs Trausta Dorsteinssyni (bls. 35-53). Reykjavík: Háskólaútgáfan. 
Auður Pálsdóttir. (2014). Sustainability as an emerging curriculum area in Iceland. The development, validation and application of a SEIQ-questionnaire (doktorsritgerð). Sótt af http://hdl.handle.net/1946/23795

Auður Pálsdóttir. (2017). Læsi á náttúruvísindi.Vísbendingar úr PISA 2015. Í Menntamálastofnun (útgefandi), Helstu niðurstöður PISA 2015 (bls. 36-42). Sótt af https://mms.is/sites/mms.is/files/helstu_ nidurstodur_pisa_2015_prent_-_loka.pdf

Birna Svanbjörnsdóttir. (2015). Leadership and teamwork in a new school: Developing a professional learning community (doktorsritgerð). Sótt af http://hdl.handle.net/1946/20818

Blitz, C. L. og Schulman, R. (2016). Measurement instruments for assessing the performance of professional learning communities. Sótt af http://files.eric.ed.gov/fulltext/ED568594.pdf

Bredeson, P.V. (2003). Designs for learning. A new architecture for professional development in schools. Thousand Oaks: Corwin.

Brown, C. og Zhang, D. (2017). How can school leaders establish evidence-informed schools: An analysis of the effectiveness of potential school policy levers. Educational Management, Administration and Leadership, 45(3), 382-401. https://doi.org/10.1177/1741143215617946

Brown, T. A. (2015). Confirmatory factor analysis for applied research. New York: Guilford.

Burns, M. K., Naughton, M. R., Preast, J. L., Wang, Z., Gordon, R. L., Robb,V. og Smith, M. L. (2017). Factors of professional learning community implementation and effect on student achievement. Journal of Educational and Psychological Consultation, 28(4), 394-412. doi:10.1080/10474412.2017.1385396

Darling-Hammond, L. (2017). Teacher education around the world: What can we learn from international practice? European Journal of Teacher Education, 40(3), 291-309. doi:10.1080/02619768.2017.1315399

Darling-Hammond, L., Hyler, M. og Gardner, M. (2017). Effective teacher professional development. Sótt af https://learningpolicyinstitute.org/sites/default/files/product-files/Effective_Teacher_Professional_Development_REPORT.pdf

Dogan, S. og Adams, A. (2018). Effect of professional learning communities on teachers and students: Reporting updated results and raising questions about research design. School Effectiveness and School Improvement, 29(4), 634-659. doi:10.1080/09243453.2018.1500921

Fullan, M. (2016). The new meaning of educational change (5. útgáfa). New York: Teachers College Press.

George, D. og Mallery, M. (2010). SPSS for Windows step by step: A simple guide and reference [17.0 update]. Boston: Pearson.

Gerður G. Óskarsdóttir, o.fl. (2014). Meginniðurstöður og umræða. Í Gerður G. Óskarsdóttir (ritstjóri). Starfshœettir í grunnskólum við upphaf 21. aldar (bls. 232-347). Reykjavík: Háskólaútgáfan.

Hairon, S., Goh, J. W. P., Chua, C. S. K. og Wang. L. (2017). A research agenda for professional learning communities: Moving forward. Professional Development in Education, 43(1), 72-86. doi:10.1080/19415257.2 015.1055861

Harris, A. (2013). Building the collective capacity for system change: Professional learning communities in Wales. Í H.J. Malone, (ritstjóri), Leading educational change. Global issues, challenges. and lessons on whole-system reform (bls. 109-113). New York: Teachers College Press.

Hord, S. M. (1997). Professional learning communities: Communities of continuous inquiry and improvement. Austin, TX: Southwest Educational Development Labratory.

Hoy, W. K. og Miskel, C. G. (2013). Educational administration: Theory, research, and practice (9. útgáfa). New York: McGraw-Hill.

Huffman, J. B., Olivier, D. F., Wang, T., Chen, P., Hairon, S. og Pang, N. (2016). Global conceptualization of the professional learning community process: Transitioning from country perspectives to international commonalities. International Journal of Leadership in Education: Theory and Practice, 19(3), 327-351. doi:10. 1080/13603124.2015.1020343

Jensen, B., Sonnemann, J., Roberts-Hull, K. og Hunter, A. (2016). Beyond PD: Teacher professional learning in high-performing systems. Sótt af http://ncee.org/wp-content/uploads/2015/08/BeyondPDDec2016.pdf

Joyce, B. og Showers, B. (2002). Student achievement through staff development (3. útgáfa). Alexandria: Longman.

Kools, M. og Stoll, L. (2016). What makes a school a learning organisation? OECD Education Working Papers, No. 
137. doi:10.1787/5jlwm62b3bvh-en

Lomos, C., Hofman, R. H. og Bosker, R. J. (2011). Professional communities and student achievement: A meta-analysis. School Effectiveness and School Improvement, 22(2), 121-148.

Louise, K. S. og Murphy,J. F. (2018). The potential of positive leadership for school improvement:A cross-disciplinary synthesis. Nordic Journal of Comparative and International Education (NJCIE), 2(2-3), 164-180. doi: $10.7577 /$ njcie. 2790

Lög um grunnskóla nr. 91/2008.

Menntamálastofnun. (2017). Helstu niðurstöður PISA 2015. Sótt af https://mms.is/sites/mms.is/files/helstu_nidurstodur_pisa_2015_prent_-_loka.pdf

Mennta- og menningarmálaráđuneytið. (2019). Samstarfsrád um starfspróun kennara og skólastjórnenda. Skýrsla til mennta- og menningarmálarádherra. Sótt af https://www.stjornarradid.is/lisalib/getfile.aspx?itemid=349b2e00ef44-11e9-944e-005056bc530c

OECD [The Organisation for Economic Co-operation and Development]. (2019). TALIS 2018 Results (volume I): Teachers and school leaders as lifelong learners. doi:10.1787/1d0bc92a-en

Olivier, D. F. og Hipp, K. K. (2010). Assessing and analyzing schools as professional learning communities. Í K. K. Hipp og J. B. Huffman (ritstjórar), Demystifying professional learning communities: School leadership at its best (bls. 29-42). Lanham, MD: Rowman \& Littlefield.

Ragnar F. Ólafsson. (2014). TALIS 2013: Starfsaðstæður, viðhorf og kennsluhœttir kennara og skólastjóra á Íslandi í alpjóðlegum samanburði. Sótt af https://mms.is/sites/mms.is/files/talis_skyrsla_2014.pdf

Ragnar F. Ólafsson. (2019). TALIS 2018: Starfshattir og viðhorf kennara og skólastjóra á unglingastigi grunnskóla. Sótt af https://mms.is/sites/mms.is/files/vefutgafa_-_talis_2019.pdf

Schreiber, J. B., Nora, A., Stage, F. K., Barlow, E. A. og King, J. (2006). Reporting structural equation modeling and confirmatory factor analysis results: A review. The Journal of Educational Research, 99(6), 323-338.

Senge, P. M., Cambron-McCabe, N., Lucas, T., Smith, B., Dutton, J. og Kleiner,A. (2000). Schools that learn: A fifth discipline fieldbook for educators, parents, and everyone who cares about education. London: Nicholas Brealey.

Sleegers, P., den Brok, P., Verbiest, E., Moolenaar, N. M. og Daly, A. J. (2013). Toward conceptual clarity: A multidimensional, multilevel model of professional learning communities in Dutch elementary schools. The Elementary School Journal, 114(1), 118-137. doi:10.1086/671063

Spillane, J. (2006). Distributed leadership. San Francisco: Jossey-Bass.

Stewart, D. og Prebble, T. (1993). The reflective principal: School development within a learning community. Palmerston North: ERDC Press.

Stjórnarrád Íslands. (2018). Heimsmarkmið Sameinuðu pjóðanna um sjálfbæra próun. Stöðuskýrsla. Sótt af https://www.stjornarradid.is/lisalib/getfile.aspx?itemid=10adb4fe-7989-11e8-942c-005056bc530c

Stoll, L., Bolam, R., McMahon, A., Wallace, M. og Thomas, S. (2006). Professional learning communities: A review of the literature. Journal of Educational Change, 7(4), 221-258.

Vesco, V., Ross, D. og Adams, A. (2008). A review on the impact of professional learning communities on teaching practice and student learning. Teaching and Teacher Education, 24(1), 80-91.

Vieluf, S., Kaplan, D., Klieme, E. og Bayer, S. (2012). Teaching practices and pedagogical innovations: Evidence from TALIS. doi:1787/9789264123540-en

Zwick, W. R. ogVelicer, W. F. (1986). Comparison of five rules for determining the number of components to retain. Psychological Bulletin, 99(3), 432-442.

Berglind Gísladóttir, Auður Pálsdóttir, Anna Kristín Sigurðardóttir og Birna Svanbjörnsdótti, (2019).

Mat á stöđu lærdómssamfélags í grunnskóla. Próun mælitækis.

Netla - Veftímarit um uppeldi og menntun. Menntavísindasvið Háskóla Íslands.

Sótt af http://netla.hi.is/greinar/2019/ryn/15

DOI: https://doi.org/10.24270/netla.2019.15 